\title{
Major surgical trauma differentially affects T-cells and APC
}

\author{
Markus Albertsmeier', Dominik Quaiser', \\ Vera von Dossow-Hanfstingl ${ }^{2}$, Hauke Winter', \\ Eugen Faist' and Martin K Angele'
}

SAGE

\begin{abstract}
Macrophages have been reported to initiate immunosuppression following trauma and hemorrhage, and recent experimental studies suggest a pivotal role of T-cells in maintaining immunosuppression. The aim of the present study was to investigate the interaction of APC and T-cells in humans following major surgery. First, APC and T-cells from I4 surgical patients were isolated, counted and characterized by their specific surface marker profile 2 and $24 \mathrm{~h}$ postoperatively. Then, these cells were co-incubated with cells of the other type, which had been isolated pre-operatively. Chemokine secretion from pre-operative cells as measured by enzyme immunoassay served as a bioassay for the function of the stimulating postoperative cells. $\mathrm{CD} 3^{+}$T-cells and surface marker $\mathrm{CD} 28$ were markedly suppressed postoperatively, while $\mathrm{CD} 3^{+} \mathrm{CD} 25^{+} \mathrm{CD} / 27^{-} \mathrm{T}_{\text {reg }} \mathrm{s}$ were not suppressed. $\mathrm{CDI} / 4^{+} \mathrm{APC}$ counts were increased with the most significant increase observed in $\mathrm{CDI}^{+}{ }^{+} \mathrm{HLA}_{-} \mathrm{DR}^{-}$myeloid-derived suppressor cells. In co-cultures, APC showed increased postoperative secretion of TNF- $\alpha$ and IL-6 independently of whether they had been co-incubated with pre- or postoperative T-cells. T-cells incubated with $\mathrm{CDI} 4^{+}$cells $2 \mathrm{~h}$ postoperatively secreted diminished amounts of IFN- $\gamma$. The results of the study suggest that T-cells play a pivotal role in mediating immunosuppression after major abdominal surgery.
\end{abstract}

\section{Keywords}

Trauma, hemorrhage, Ag-presenting cells, T-cells, monocytes, cellular immune response

Date received: 27 June 20I3; revised: 16 September 20I3; 27 October 2013; accepted: 20 November 2013

\section{Introduction}

Major surgical trauma and blood loss result in a depression of cell-mediated immunity. ${ }^{1,2}$ In particular, the interaction between APC and T-cells, which has been shown to play a pivotal role in the induction of an adequate cell-mediated immune response, is altered after trauma hemorrhage. ${ }^{3,4}$ Depression of T-cells and APC has been demonstrated $7 \mathrm{~d}$ after surgery and is associated with an increased susceptibility to infection. ${ }^{5}$

Various mechanisms in both APC and T-cells are thought to be responsible for an insufficient interaction of the different cell types. In this respect, MHC II expression by APC is suppressed after trauma and blood loss, resulting in decreased Ag presentation. ${ }^{6}$ In addition, LPS-induced IL-12 release capacities of APC are diminished after trauma and blood loss. ${ }^{7}$ APCderived IL-12 has been shown to activate T-cell responses, that is, the release of IFN- $\gamma$ and IL-2. Conversely, the synthesis and release of IL-12 appears to be regulated by T-cell-derived IFN- ${ }^{8}{ }^{8}$
On T-cells, distinct components of the T-cell receptor (TCR) complex (TCR- $\alpha$ and TCR- $\beta$ chains, ${ }^{9,10}$ as well as the invariable $\mathrm{CD} 3$ proteins) and co-stimulatory molecules (CD4, CD8 and CD28) have been identified to be required for APC-T-cell interaction. ${ }^{11}$ Trauma and surgery lead to a significant decrease in total lymphocyte counts and T-cell proliferation, which is associated with a shift from pro-inflammatory Th1 cytokine production (i.e. IL-2, IFN- $\gamma$ ) to an increased

\footnotetext{
'Department of General, Visceral, Transplantation, Vascular and Thoracic Surgery, Klinikum Großhadern, Ludwig-Maximilian University, Munich, Germany

${ }^{2}$ Department of Anaesthesiology, Klinikum Großhadern, LudwigMaximilian University, Munich, Germany

Corresponding author:

Martin Angele, Department of General, Visceral, Transplantation, Vascular and Thoracic Surgery, Klinikum Großhadern, Marchioninistr. I5, D-8I377 Munich, Germany.

Email: martin.angele@med.uni-muenchen.de
} 
release of potentially immunosuppressive Th2 cytokines (i.e. IL-4, IL-10) mediated by regulatory T-cells $\left(\mathrm{T}_{\text {reg }} \mathrm{s}\right) .{ }^{2,7} \mathrm{Th} 2$ cytokines increase the expression of arginase-1 in myeloid-derived suppressor cells (MDSCs), causing an arginine deficiency state, which further impairs lymphocyte function. ${ }^{2,12,13}$

Although numerous studies have been directed towards these immune cells and the distinct processes of their interaction after trauma and surgery, it is not known which immune cell type is predominately responsible for immunosuppression in humans under these conditions. Experimental studies in mice suggest that APC initiate immunosuppression after trauma and blood loss, ${ }^{14}$ whereas T-cells play a key role in the perpetuation of diminished T-cell-APC interaction. ${ }^{15}$ In particular, trauma-hemorrhaged $\mathrm{T}$-cells depress cytokine responses and the expression of MHC II by APC irrespective of whether APC were subjected to trauma hemorrhage or sham operation.

The aim of the present study, therefore, was to investigate the T-cell-APC interaction in patients after major abdominal surgery in order to clarify the immunosuppressive effect of APC on T-cells in the clinical setting. The results from the present study may help to further elucidate the pathophysiological mechanisms of immunosuppression following major abdominal surgery and thus allow for the development of new targets for specific immunotherapy.

\section{Materials and methods}

\section{Study design}

This study was designed as a prospective observational trial with consecutive measurements and pre-operative values serving as internal controls. It was conducted in the Department of General, Visceral, Transplantation, Vascular and Thoracic Surgery at Großhadern Hospital, Ludwig-Maximilians University, in Munich, Germany. The study protocol was approved by the local institutional review board.

\section{Study patients}

The study included adults undergoing elective major abdominal surgery-upper gastrointestinal surgery, hepatic or pancreatic resection. The exclusion criteria were chemotherapy or immunosuppressive therapy within the past $12 \mathrm{mo}$, pregnancy, liver cirrhosis, malnutrition and lack of informed consent. After having obtained their informed consent, 12 patients were included. Characteristics and peri-operative data from patients included in this study are outlined in Table 1.

\section{Study protocol}

Three times were defined for measurements: $1 \mathrm{~h}$ preoperatively as an internal control, and 2 and $24 \mathrm{~h}$
Table I. Patient characteristics.

\begin{tabular}{ll}
\hline Number of patients & 14 \\
Male & $7(50 \%)$ \\
Female & $7(50 \%)$ \\
Age $(y)$ & $54( \pm 8)$ \\
Type of surgery & \\
Liver resection & 10 \\
Pancreatic resection & 3 \\
Gastrectomy & 1 \\
Blood loss $(\mathrm{ml})$ & $1423( \pm 500)$ \\
Patients with blood loss & \\
$\quad<$ I.000 $\mathrm{ml}$ & 4 \\
I.000 $\mathrm{ml}-2.000 \mathrm{ml}$ & 7 \\
$>2.000 \mathrm{ml}$ & 3 \\
Hemoglobin drop $(\mathrm{mg} / \mathrm{dl})$ & $3.9( \pm \mathrm{I} .2)$ \\
Min. systolic blood pressure $(\mathrm{mm} \mathrm{Hg})$ & $70( \pm 5)$ \\
Max. noradrenaline dose $(\mathrm{mg} / \mathrm{h})$ & $0.5( \pm 0.3)$ \\
\hline
\end{tabular}

postoperatively (Figure 1). Blood $(40 \mathrm{ml})$ was drawn at these three times and, in addition, $24 \mathrm{~h}$ pre-operatively, from all patients. Two types of experiments were then conducted with these samples: first, FACS analysis for surface marker expression at the predefined times was performed; second, co-cultures of T-cells and APC were established from these samples and from untreated $24 \mathrm{~h}$ pre-operative blood. Cytokine secretion from these co-cultures was then determined using enzyme immunoassays. The experimental procedures, in detail, were as follows.

\section{PBMC isolation}

PBMC were separated using a standard FicollHypaque density gradient (BioChrom AG, Berlin, Germany). Briefly, blood was diluted at a 1:1 ratio with Hank's balanced salt solution (HBSS; Lonza, Walkersville, MD, USA) layered on top of the Ficoll Hypaque in $50-\mathrm{ml}$ tubes and centrifuged for $25 \mathrm{~min}$ at $900 \mathrm{~g}$. PBMC were collected using a medical syringe. Cells were then re-suspended in HBSS, counted and stored on ice at $4{ }^{\circ} \mathrm{C}$. Viability of PBMC was consistently $>95 \%$, as determined by trypan blue exclusion.

\section{APC and T-cell separation}

APC and T-cells were purified in two sequential positive selection steps using magnetic-activated cell sorting kits (MACS; Miltenyi Biotec, Bergisch Gladbach, Germany) with magnetic beads labeling the target cells as described by the manufacturer. Briefly, after centrifugation ( 5 mins at $400 \mathrm{~g}$ ), cells were re-suspended in $80 \mu \mathrm{l}$ MACS buffer and $20 \mu \mathrm{l}$ CD14 magnetic Mircrobeads (Miltenyi Biotec) per $10^{7}$ cells and incubated at $4-8^{\circ} \mathrm{C}$ for 15 mins. The suspension with labeled 


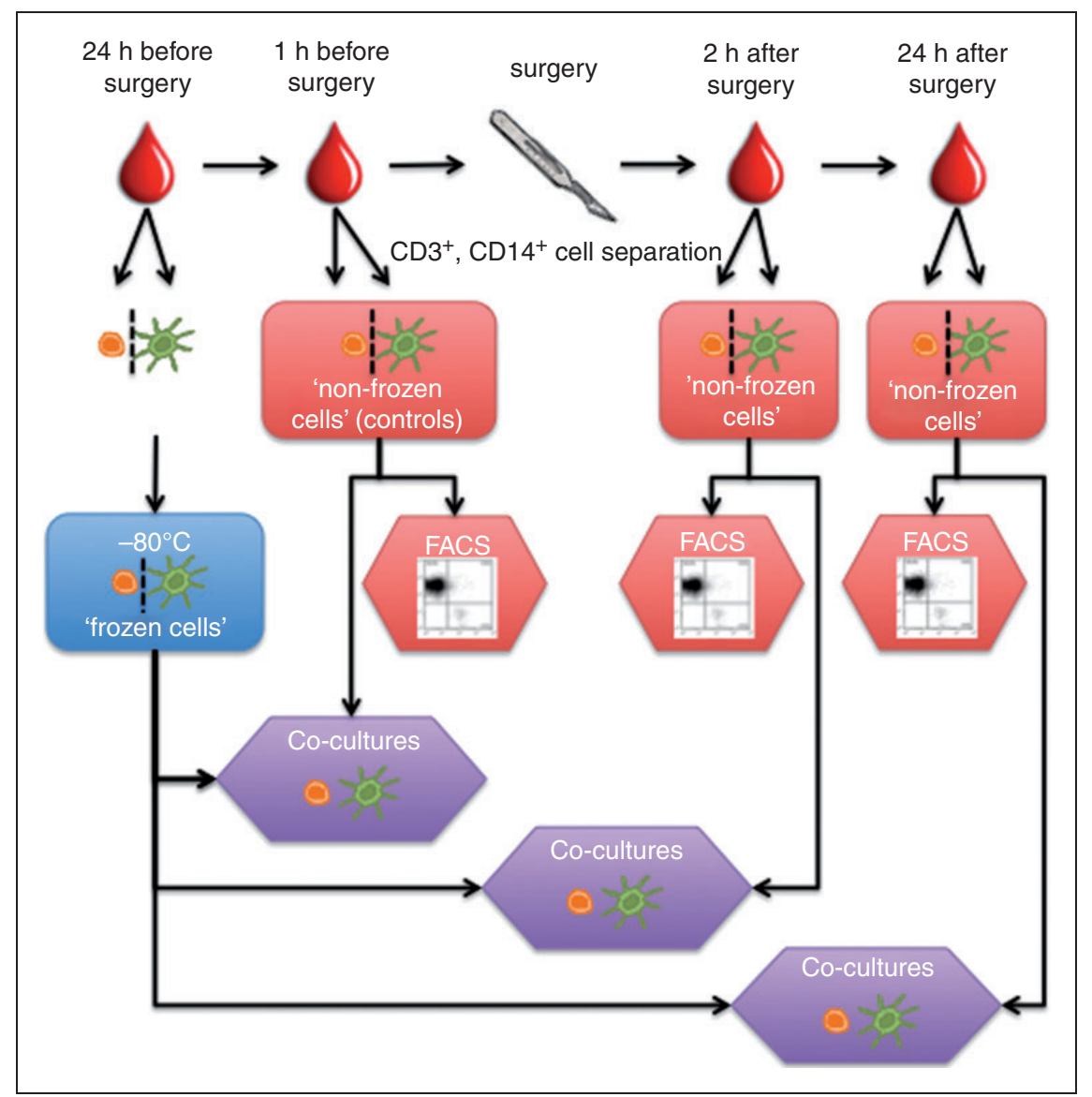

Figure I. Sample acquisition and cell utilization. For FACS analysis, cells were used without further treatment. Co-cultures were established using pre-operative 'frozen' together with pre- and postoperative 'non-frozen' cells. IL secretion from the pre-operative 'frozen' cells served as a bioassay for the function of the pre-operative controls or postoperative cells that they were incubated with.

$\mathrm{CD} 14^{+}$cells was diluted in $1-2 \mathrm{ml}$ buffer and centrifuged at $300 \mathrm{~g}$ for 5 mins. Cells were re-suspended in $500 \mu 1$ MACS buffer and applied to the MACS column. $\mathrm{CD} 14^{+}$cells labeled with magnetic beads adhered to the column, while non-labeled cells were rinsed with $500 \mu 1$ MACS buffer three times. Magnet-sorted cells were eluted from the column to a separate vessel using $1 \mathrm{ml}$ buffer after removing the column from the magnetic field.

For $\mathrm{CD}^{+}$cell purification, the suspension passed through the column and was thus depleted of CD14 ${ }^{+}$ cells, and was again centrifuged for $5 \mathrm{~min}$ at $400 \mathrm{~g}$. Cells were then re-suspended in $80 \mu \mathrm{l}$ MACS buffer and, this time, $20 \mu \mathrm{CD} 3$ magnetic microbeads per $10^{7}$ cells and incubated at $4-8^{\circ} \mathrm{C}$ for 15 mins. This suspension with labeled $\mathrm{CD}^{+}$cells was then processed and applied to the MACS column as described above.

To confirm purity, $2 \times 10^{5}$ cells were aliquoted from both the fractions held back and the fractions flown through the column and analyzed by flow cytometry. Sorted cells were $>99.5 \%$ pure, as determined by postsort analysis for $\mathrm{CD}^{+}$or $\mathrm{CD} 14^{+}$cells. Purified cells were centrifuged at $400 \mathrm{~g}$ for 5 mins and then suspended in $1 \mathrm{ml}$ medium (90\% RPMI 1640 GlutaMAX-1 and $10 \%$ FCS), counted and stored on ice.

\section{Utilization of separated APC and T-cells}

Cells harvested $24 \mathrm{~h}$ before surgery were frozen at $-80^{\circ} \mathrm{C}$ using a buffer system with $70 \%$ RPMI 1640 GlutaMax-1, 20\% FCS and 10\% DMSO for APC and T-cells. Those cells were thawed on the day of surgery or the following day for the establishment of cocultures. Henceforth, those cells will be named 'frozen APC' or 'frozen T-cells', respectively (Figure 1).

Separated T-cells and APC harvested preoperatively on the day of surgery, and 2 and $24 \mathrm{~h}$ postoperatively were used for flow cytometry analysis and co-culturing without freezing. Henceforth, these cells are named 'non-frozen APC' or 'non-frozen T-cells', respectively.

\section{Co-cultures of APC and T-cells}

Separated non-frozen or frozen APC $\left(\mathrm{CD} 14^{+}\right.$cells) and non-frozen or frozen $\mathrm{T}$-cells $\left(\mathrm{CD}^{+}\right.$cells) were 
co-cultured in 48-well culture plates. For each time point, the designed co-culture system resulted in four experimental groups:

- group 1-frozen T-cells + frozen APC (control group);

- group 2-non-frozen T-cells + non-frozen APC (the 'normal' non-frozen situation);

- group 3-frozen T-cells + non-frozen APC (to study the influence of APC on T-cells);

- group 4 -non-frozen T-cells + frozen APC (to study the influence of T-cells on APC).

Co-cultures were stimulated using LPS for APC stimulation and anti-CD3, as well as anti-CD28 for T-cell stimulation. Three separate plates (pre-operative, and 2 and $24 \mathrm{~h}$ postoperative) were prepared for each patient with pre-coated anti-CD3-Abs (250 $\mu$; Miltenyi Biotec) and rinsed three times with $300 \mu \mathrm{HBSS}$.

Co-cultures were incubated in $1 \mathrm{ml}$ of DMEM (GIBCO, Invitrogen, Carlsbad, CA, USA) with $10 \%$ inactivated FCS (Cambrex, Verviers, Belgium) and $0.1 \%$ Gentamycin (Bio Whittaker, Verviers, Belgium) for $48 \mathrm{~h}$ at $37^{\circ} \mathrm{C}$ and $5 \% \mathrm{CO}_{2}$. In addition to anti-CD3 (pre-coated plates), cells were stimulated with $20 \mu \mathrm{l}$ anti-CD28 Abs (Miltenyi Biotec) and $1 \mu \mathrm{g} / \mathrm{ml}$ LPS from Escherichia coli 055: B5 $(<3 \%$ protein, TCA extracted; Sigma, St Louis, MO, USA).
After $48 \mathrm{~h}$ of incubation, the supernatants were harvested, aliquoted and stored at $-70^{\circ} \mathrm{C}$ for cytokine measurements.

\section{Assessment of cytokines}

IL-6, IL-12, GM-CSF, TNF- $\alpha$ (TNF) and IFN- $\gamma$ were determined in the supernatants by multiplex assay (BioRad Laboratories, Hercules, CA, USA) as per the manufacturer's instructions. In brief, for multiplex assay, $50 \mu \mathrm{l}$ of each sample was allowed to react with the cytokine-specific Ab-conjugated beads in microplate wells. The flow-based Bio-Plex protein array system identifies and quantifies each specific reaction based on bead colours according to the manufacturer's information. The magnitude of the reaction was measured using fluorescently-labeled reporter molecules, also specific to each target protein.

\section{Flow cytometry}

Isolated non-frozen cells harvested $1 \mathrm{~h}$ before surgery, as well as 2 and $24 \mathrm{~h}$ after surgery, were washed with buffer (11 PBS, $0.5 \%$ BSA, $0.002 \% \mathrm{NaN}_{3}$ ) at $700 \mathrm{~g}$ for 5 mins and subsequently incubated with $2 \mu \mathrm{FcR}$ receptor blocking solution for 15 mins at $4^{\circ} \mathrm{C}$. After a second washing, FACS Abs were distributed and labeled as detailed in Table 2, and tubes were again incubated at

Table 2. Abs used for FACS analysis.

\begin{tabular}{|c|c|c|c|c|}
\hline$A b$ & Clone & Clone & Manufacturer & Isotype \\
\hline FcR Block human & & & Miltenyi Biotec & \\
\hline $\lg G \mid$ & IS5-2IF5 & FITC & Miltenyi Biotec & Mouse IgGI \\
\hline $\lg G \mid$ & IS5-2IF5 & $\mathrm{PE}$ & Miltenyi Biotec & Mouse IgGI \\
\hline $\lg G 2 a$ & S43.10 & $\mathrm{PE}$ & Miltenyi Biotec & Mouse IgG2a \\
\hline $\lg G \mid$ & $\times 40$ & PerCP Cy5.5 & BD Bioscience & Mouse $|g G|$ \\
\hline$|g G|$ & IS5-2IF5 & APC & Miltenyi Biotec & Mouse IgGI \\
\hline $\lg G 2 a$ & $S 43.10$ & APC & Miltenyi Biotec & Mouse IgG2a \\
\hline CD3 & BW264/56 & $\mathrm{PE}$ & Miltenyi Biotec & Mouse IgG2a \\
\hline CD4 & M-T466 & FITC & Miltenyi Biotec & Mouse IgGI \\
\hline CD8 & RPA-T8 & PerCP Cy5.5 & eBioscience & Mouse IgGI,K \\
\hline CDI4 & TüK4 & APC & Miltenyi Biotec & Mouse IgG2a \\
\hline CDI6 & VEPI3 & FITC & Miltenyi Biotec & Mouse IgM \\
\hline $\mathrm{CD} 25$ & $4 \mathrm{E} 3$ & APC & Miltenyi Biotec & Mouse $\lg G 2 b$ \\
\hline CD28 & I5E8 & APC & Miltenyi Biotec & Mouse IgGI \\
\hline CD40 & $5 C 3$ & FITC & BD Pharmingen & Mouse IgGI,א \\
\hline CD69 & FN50 & APC & Miltenyi Biotec & Mouse IgGI \\
\hline CD80 & L307.4 & PE & BD Pharmingen & Mouse IgGI,א \\
\hline CD86 & $2331(F U N-I)$ & FITC & BD Pharmingen & Mouse IgGI,א \\
\hline CDI27 & eBioRDR5 & PerCP Cy5.5 & eBioscience & Mouse IgGI \\
\hline CDI54 & TRAPI & FITC & BD Pharmingen & Mouse IgGI,K \\
\hline HLA-DR & G46-6 & $\mathrm{PE}$ & BD Pharmingen & Mouse $\lg G 2 \mathrm{a}, \mathrm{K}$ \\
\hline
\end{tabular}




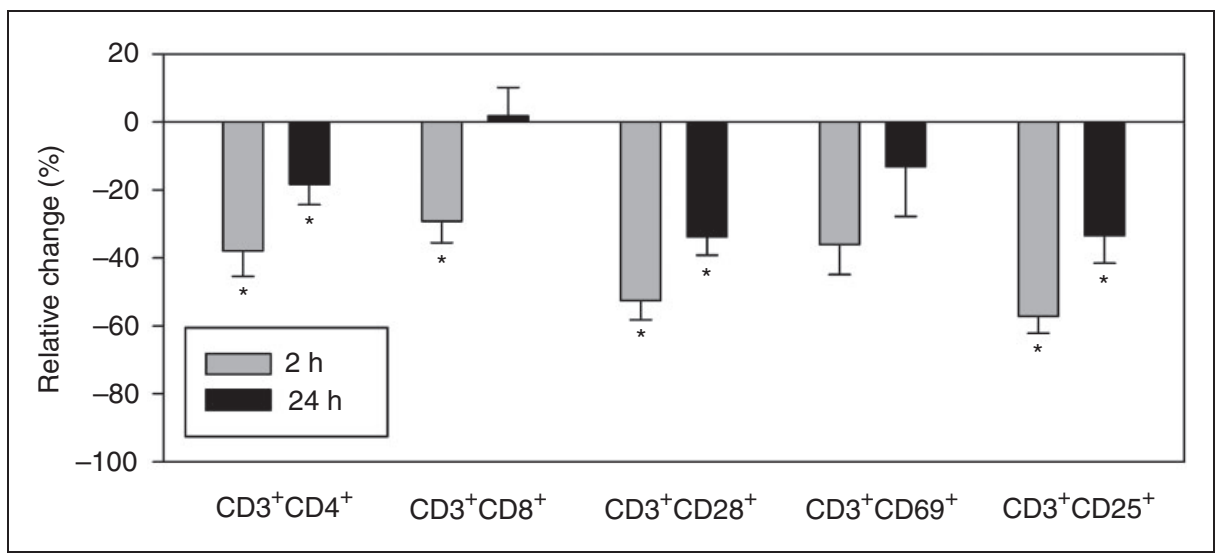

Figure 2. Postoperative changes in $\mathrm{CD}^{+}$subpopulations. This graph shows relative changes in $\mathrm{CD}^{+}$subpopulations compared with pre-operative measurements. Most $\mathrm{CD}^{+}$subpopulations are suppressed postoperatively, at $2 \mathrm{~h}$ more than at $24 \mathrm{~h}$. Of all subtypes analyzed, suppression of $\mathrm{CD}^{+} \mathrm{CD} 4^{+}, \mathrm{CD}^{+} \mathrm{CD} 28^{+}$and $\mathrm{CD} 3^{+} \mathrm{CD} 25^{+}$cells was the strongest, while suppression of $\mathrm{CD} 3^{+} \mathrm{CD} 69^{+}$cells was statistically not significant. ${ }^{*} P<0.05$ compared with pre-operative values.

$4^{\circ} \mathrm{C}$ for 15 mins. Unbound Abs were washed away at $700 \mathrm{~g}$ for 5 mins and cells stored at $4^{\circ} \mathrm{C}$ until analysis [FACS Calibur (Becton Dickinson, Bedford, MA, USA) connected to computer system (Coulter EPICS XL (Beckman Coulter, Krefeld, Germany) CA, USA)]. To analyze the expression of specific surface markers, ratios of subpopulations and their corresponding overall population were calculated (e.g. $\mathrm{CD}^{+} \mathrm{CD} 28^{+} /$ $\mathrm{CD}^{+}$) and pre-operative versus postoperative values compared. A positive or negative change in these ratios corresponds to an overexpression or suppression, respectively, of the specific surface marker (e.g. CD28) within the corresponding overall cell population (e.g. $\mathrm{CD}^{+}$cells).

\section{Statistical analysis}

Data are presented as mean \pm SEM. Measurements from samples acquired 2 and $24 \mathrm{~h}$ postoperatively were compared with pre-operative measurements. ANOVA was used to adjust for these multiple comparisons. The Holm-Sidak post hoc test was used where appropriate. SigmaStat (v3.0; Systat, Chicago, IL, USA) software was used for statistical analysis. A $P$-value of $\leq 0.05$ was deemed significant.

\section{Results}

\section{Cell surface markers}

$\mathrm{CD}^{+} \mathrm{T}$-cells were significantly suppressed $2 \mathrm{~h}(-38 \%$; $P<0.001)$ and $24 \mathrm{~h}(-23 \% ; P<0.001)$ postoperatively, while $\mathrm{CD}_{14}{ }^{+}$APC were induced at $2 \mathrm{~h}(+64 \%$; $P<0.001)$ and $24 \mathrm{~h}(+71 \% ; P<0.001)$.

Surface markers on T-cells. The subset of $\mathrm{CD}^{+}{ }^{+} \mathrm{CD} 28^{+}$ cells was suppressed 2 and $24 \mathrm{~h}$ after surgery as compared with pre-operative measurements. In addition,

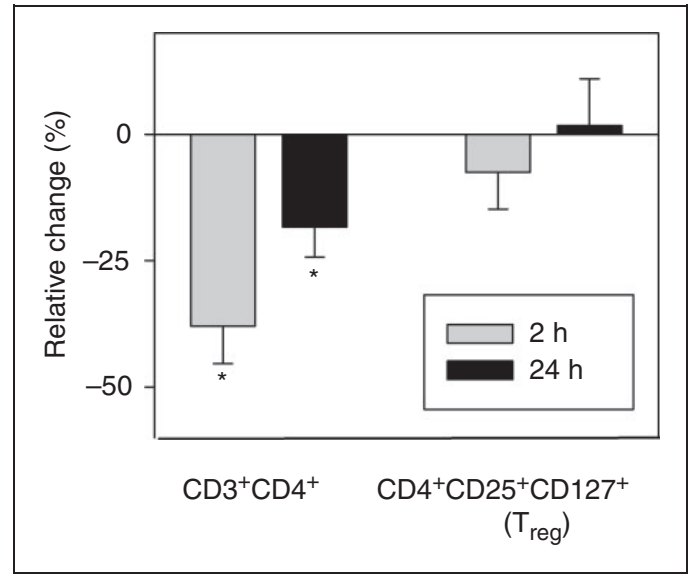

Figure 3. $\mathrm{CD}^{+}$subgroup analysis. As with other $\mathrm{CD} 3^{+}$cells, $\mathrm{CD}^{+} \mathrm{CD}^{+}$cells are suppressed postoperatively. The subgroup of $\mathrm{CD}^{+} \mathrm{CD}^{2} 5^{+} \mathrm{CD} 127^{-} \mathrm{T}_{\text {regs }}$, however, are not suppressed. $* P<0.05$ compared with pre-operative values.

the $\mathrm{CD}^{+}{ }^{+} \mathrm{CD} 28^{+} / \mathrm{CD}^{+}$ratio was significantly reduced 2 and $24 \mathrm{~h}$ postoperatively, that is, the expression of surface marker CD28 was significantly reduced on $\mathrm{CD}^{+}$cells following surgery. Counts of $\mathrm{CD} 3^{+} \mathrm{CD} 25^{+}$ cells were similarly reduced 2 and $24 \mathrm{~h}$ postoperatively, with a significant drop in the $\mathrm{CD} 3^{+} \mathrm{CD} 25^{+} / \mathrm{CD} 3^{+}$ratio at $2 \mathrm{~h}$, but not $24 \mathrm{~h}$. Finally, fewer $\mathrm{CD}^{+} \mathrm{CD}^{+} 9^{+}$cells were found postoperatively, although this decrease was not significant. The $\mathrm{CD} 3^{+} \mathrm{CD} 69^{+} / \mathrm{CD}^{+}$ratio did not change postoperatively.CD ${ }^{+} \mathrm{CD} 4^{+}$T-helper cells were significantly suppressed 2 and $24 \mathrm{~h}$ after surgery (Figure 2) with no change in the $\mathrm{CD}^{+} \mathrm{CD}^{+} / \mathrm{CD}^{+}$ ratio. Within the group of $\mathrm{T}$-helper cells, the subgroup of $\mathrm{CD}^{+} \mathrm{CD} 25^{+} \mathrm{CD} 127^{-} \mathrm{T}_{\text {reg }} \mathrm{s}$ remained unchanged compared with pre-operative cell counts (Figure 3). However, the $\mathrm{CD} 4{ }^{+} \mathrm{CD} 127^{+} \mathrm{CD} 25^{+} / \mathrm{CD}^{+}$ratio was significantly increased at $2 \mathrm{~h}$. 


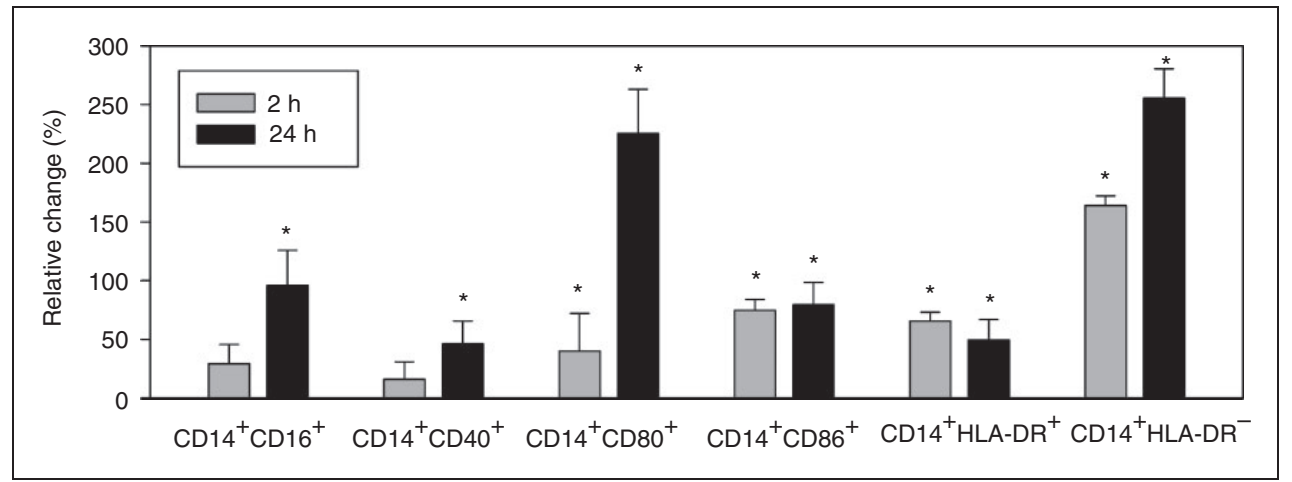

Figure 4. Postoperative changes in $\mathrm{CDI} 4^{+}$sub-populations. $\mathrm{CDI} 4^{+}$cells were induced postoperatively. The most important increase was observed for CDI4 ${ }^{+} \mathrm{HLA}_{-} \mathrm{RR}^{-}$MDSC. $* P<0.05$ compared with pre-operative values.

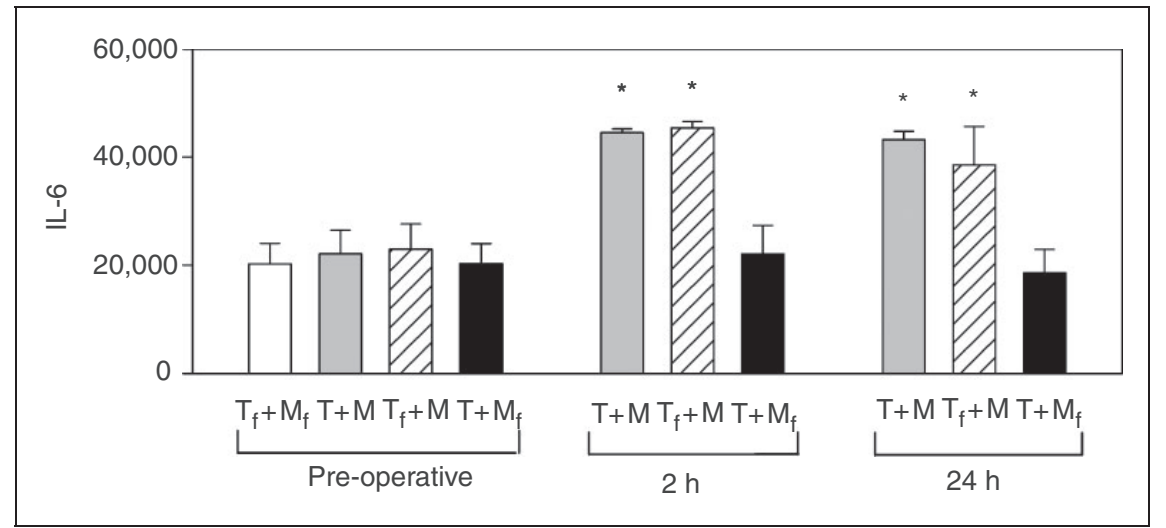

Figure 5. IL-6 production was induced in co-cultures of frozen or non-frozen T-cells with non-frozen APC, but not with frozen APC. T: T-cells; M: APC; f: frozen. $* P<0.05$ compared with pre-operative values.

$\mathrm{CD} 3^{+} \mathrm{CD} 8^{+}$cells were significantly suppressed only at $2 \mathrm{~h}$, but not at $24 \mathrm{~h}$, while no change in the $\mathrm{CD}^{+}{ }^{+} \mathrm{CD} 8^{+} / \mathrm{CD}^{+}$ratio was found. The $\mathrm{CD} 4^{+} / \mathrm{CD} 8^{+}$ ratio was only slightly reduced after surgery $(P>0.05)$.

Surface markers on APC (Figure 4). The $\mathrm{CD} 80^{+}$subset of $\mathrm{CD} 14^{+} \mathrm{APC}$ was significantly increased 2 and $24 \mathrm{~h}$ postoperatively, with no significant change in the $\mathrm{CD} 14^{+} \mathrm{CD} 80^{+} / \mathrm{CD} 14^{+}$ratio. Similarly, CD $14^{+} \mathrm{CD} 86^{+}$ cells were induced 2 and $24 \mathrm{~h}$ postoperatively. Here, a transient increase of the $\mathrm{CD} 14^{+} \mathrm{CD} 86^{+} / \mathrm{CD} 14^{+}$ratio was observed. Postoperative counts of $\mathrm{CD} 14^{+} \mathrm{HLA}-$ $\mathrm{DR}^{+}$cells were also significantly higher when compared with pre-operative values with no significant change in $\mathrm{CD} 14^{+} \mathrm{HLA}-\mathrm{DR}^{+} / \mathrm{CD} 14^{+}$ratios. The largest increase of all $\mathrm{CD}_{14}{ }^{+}$cells analyzed was observed at both 2 and $24 \mathrm{~h}$ after surgery for CD $14^{+} \mathrm{HLA}^{-D R^{-} \text {MDSC. }}$

$\mathrm{CD} 14^{+} \mathrm{CD} 16^{+}$cells were significantly induced $24 \mathrm{~h}$, but not $2 \mathrm{~h}$, after surgery, while the $\mathrm{CD} 14^{+} \mathrm{CD} 16^{+} /$ $\mathrm{CD}_{14}{ }^{+}$ratio showed a transient, but significant, decrease $2 \mathrm{~h}$ postoperatively. $\mathrm{CD} 14^{+} \mathrm{CD} 40^{+}$cells were increased 2 and $24 \mathrm{~h}$ after surgery, with no change in the $\mathrm{CD} 14^{+} \mathrm{CD} 40^{+} / \mathrm{CD} 14^{+}$ratio.

\section{Cytokine secretion from co-cultures of T-cells and $A P C$}

APC-derived cytokines. Secretion of IL-6 (Figure 5) and TNF (Figure 6) by APC harvested postoperatively and co-cultured with postoperative T-cells (group 2) was significantly increased 2 and $24 \mathrm{~h}$ after surgery as compared with pre-operative measurements. When postoperative APC were co-cultured with frozen T-cells separated pre-operatively (group 3), secretion of IL-6 and TNF was induced comparably to the co-culture system using only postoperative cells. Secretion of IL-6 or TNF by pre-operatively frozen APC was not increased when co-cultured with nonfrozen T-cells (group 4). The secretion of these cytokines was comparable to the control co-culture-system using only frozen APC and T-cells (group 1), and to pre-operative values.

The secretion of IL-12 (Figure 7) did not change postoperatively (group 2) and was not affected by coculture with frozen T-cells (group 3). It was reduced to almost undetectable levels in both co-culture systems containing frozen APC (groups 1 and 4). This reduction 


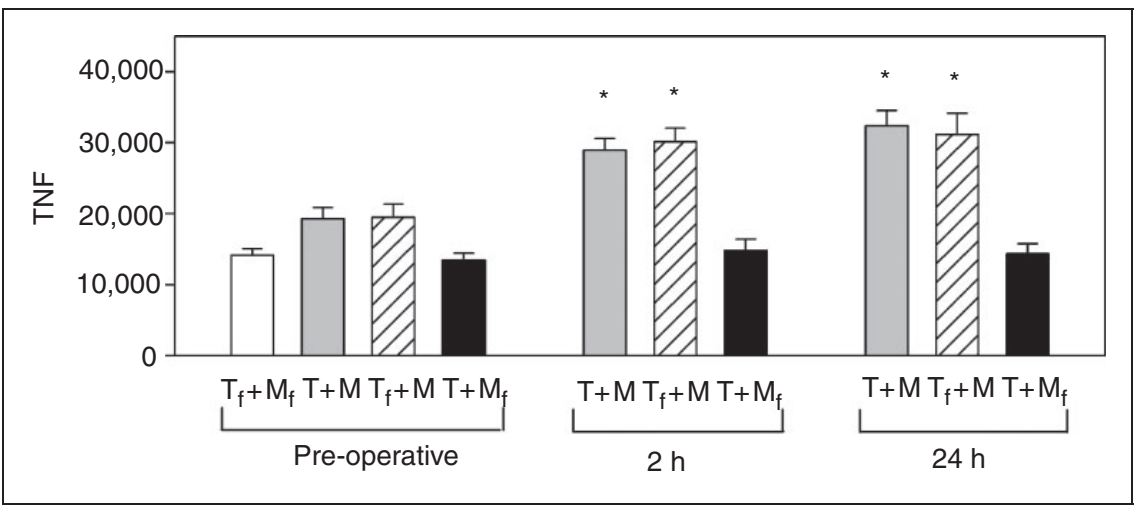

Figure 6. TNF production was induced in co-cultures of frozen or non-frozen T-cells with non-frozen APC, but not with frozen APC. T: T-cells; M: APC; f: frozen. $* P<0.05$ compared with pre-operative values.

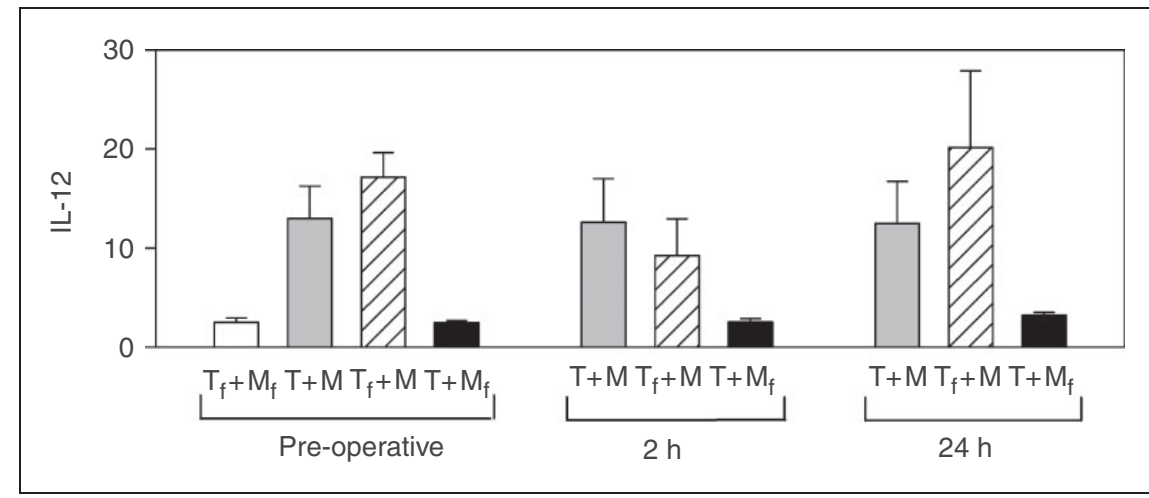

Figure 7. IL-I 2 production was reduced to undetectable levels when frozen APC were used in co-cultures. T: T-cells; M: APC; f: frozen. $* P<0.05$ compared with pre-operative values.

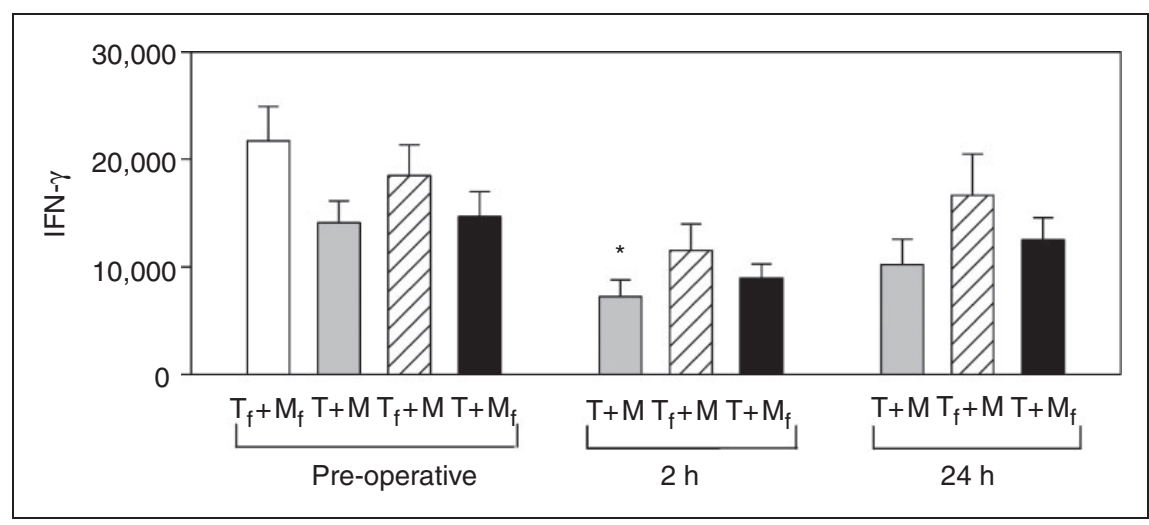

Figure 8. IFN- $\gamma$ production was suppressed $2 \mathrm{~h}$ postoperatively in co-cultures of T-cells and APC. Suppression was significant when non-frozen T-cells and APC were used but not when either T-cells or APC had been frozen. T: T-cells; M: APC; f: frozen. $*$ P $<0.05$ compared with pre-operative values.

was also observed in pre-operative controls that had been frozen on the day of surgery.

T-cell-derived cytokines. IFN- $\gamma$ from postoperative T-cells co-cultured with postoperative APC (group 2) was significantly decreased at $2 \mathrm{~h}$, but not at $24 \mathrm{~h}$ (Figure 8 ).
When frozen T-cells were co-incubated with postoperative APC (group 3), IFN- $\gamma$ secretion was transiently and not significantly suppressed at $2 \mathrm{~h}$. Similarly, the transient suppression of IFN- $\gamma$ secretion at $2 \mathrm{~h}$ from non-frozen T-cells cultured with frozen APC (group 4) was not significant. 


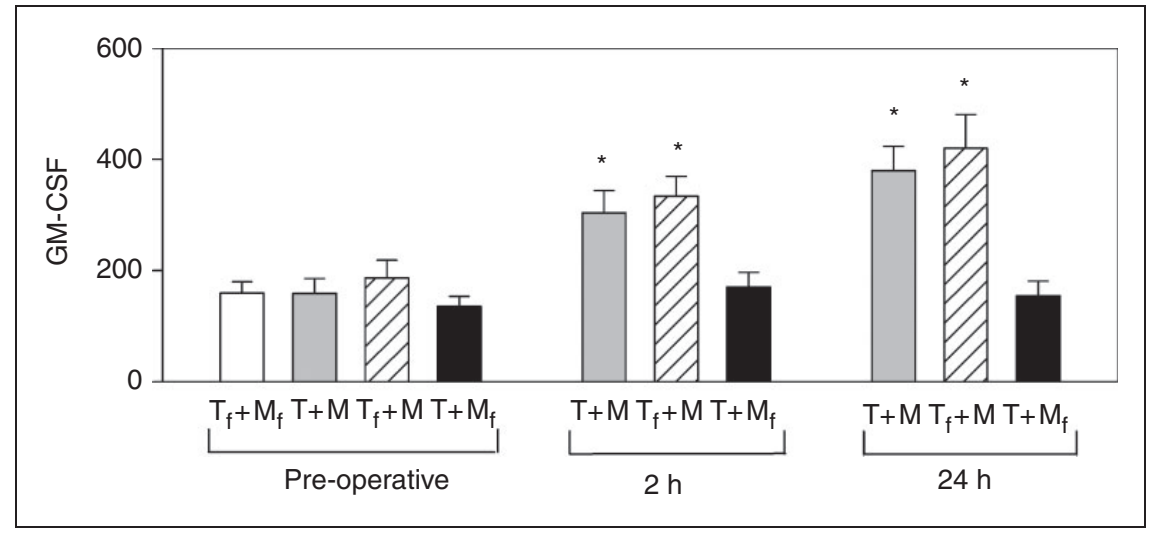

Figure 9. GM-CSF production was induced in co-cultures of frozen or postoperative T-cells with postoperative APC but not with frozen APC. T: T-cells; M: APC; f: frozen. $* P<0.05$ compared with pre-operative values.

At the same time, granulocyte macrophage colonystimulating factor (GM-CSF) secretion was increased at 2 and $24 \mathrm{~h}$ when postoperative (group 2) or frozen (group 3) T-cells were co-cultured with postoperative APC (Figure 9). When frozen APC were used (groups 1 and 4), GM-CSF secretion did not increase.

No significant postoperative changes for any cytokine were found in controls (group 1), that is, co-cultures of frozen T-cells with frozen APC.

\section{Discussion}

Abdominal surgery with blood loss causes a depression of cell-mediated immune responses resulting in an increased susceptibility to infectious complications with increased mortality. ${ }^{2}$ This immunosuppression affects, among other immune cells, both T-cells and APC. Th1-cells, for example, proliferate less and release smaller amounts of pro-inflammatory cytokines, such as IL-2 and IFN- $\gamma .{ }^{3,16}$ In addition to decreased cytokine release capacities, APC have been found to exhibit diminished MHC II expression and, thus, reduced Ag presentation. $^{6}$

The complex interaction between these two cell types plays an important role in the maintenance of regular immune function. ${ }^{14}$ Experimental findings suggest that following trauma hemorrhage, defective T-cells suppress APC and vice versa. Kawasaki et al. ${ }^{17}$ found dendritic cells isolated $2 \mathrm{~h}$ after trauma hemorrhage to cause diminished $\mathrm{T}$-cell responses in vitro, while anergic T-cells have been shown to suppress dendritic cell function. ${ }^{18}$ Similarly, recent studies by our group using a coculture system following immune cell separation demonstrated that trauma-hemorrhaged $\mathrm{T}$-cells are able to depress IL-12 release by APC. ${ }^{3}$ However, the release of the T-cell cytokine IFN- $\gamma,{ }^{3}$ as well as IL-4 and GM-CSF secretion, ${ }^{15}$ remained unaffected by trauma-hemorrhaged APC. These results suggest that IFN- $\gamma$ and other T-cell-derived cytokines contribute to immunosuppression following trauma hemorrhage causing diminished MHC II expression on APC in an experimental setting. To our knowledge, these interactions have not yet been investigated in humans undergoing major abdominal surgery.

Therefore, the aim of the present study was to investigate the changes in APC and T-cells, and how the two cell types influence each other following surgical trauma in abdominal surgery patients. To address this question, we measured surface markers on T-cells and APC, as well as cytokine responses in a co-culture system of the two cell types.

In this study, the number of patients was too small to correlate the amount of blood loss with immune responses. Moreover, no correlation between blood loss and minimum blood pressure $(\mathrm{R}=0.22)$, vasopressor dose $(R=-0.07)$ or lactate $(R=0.18)$ in our study patients was found. This suggests that that blood loss was probably too low and fluid resuscitation adequate to prevent hemorrhagic shock to occur.

Determining the effect of intra-operative blood loss on immune cell function was beyond the scope of the present study owing to the limited number of patients with excessive and small blood loss.

FACS analysis showed that $\mathrm{CD}^{+} \mathrm{T}$-cells were suppressed postoperatively, with the lowest values observed early at $2 \mathrm{~h}$. Various $\mathrm{CD}^{+}$subpopulations were likewise diminished. Interestingly, the surface molecules CD25 (at 2h) and co-stimulatory CD28 (at 2 and $24 \mathrm{~h}$ ) were reduced significantly not only when compared with pre-operative values, but also when compared with the overall $\mathrm{CD}^{+}$postoperative population. CD25 is the IL-2 receptor $\alpha$-chain ${ }^{19}$ and serves as an activation marker for T-cells. ${ }^{20} \mathrm{CD} 28$ is a co-stimulatory surface molecule on T-cells that may also activate dendritic cells via CD80 and CD86 in a reciprocal fashion. ${ }^{11}$ The suppression of activation marker CD69 may not have been significant owing to the small sample size. These results indicate a suppression of T-cell activation occurring early in the posttraumatic period. 
The expression of $\mathrm{CD} 4^{+}, \mathrm{CD} 25^{+}$and $\mathrm{CD} 127^{-}$defines a subset called $\mathrm{T}_{\text {regs. }} \mathrm{S} \mathrm{T}_{\text {reg }} \mathrm{s}$ can suppress $\mathrm{Th} 1$ immune responses and promote a shift toward Th2 anti-inflammatory immunosuppressive responses. ${ }^{2,21}$ Interestingly, these $\mathrm{CD} 4^{+} \mathrm{CD} 25^{+} \mathrm{CD} 127^{-}$cells were not suppressed postoperatively in our patients. On the contrary, when compared with overall $\mathrm{CD}^{+}$cell counts, we observed a significant relative increase of $\mathrm{T}_{\text {reg }} \mathrm{s} \mathrm{h}$ postoperatively. $\mathrm{T}_{\text {reg }} \mathrm{s}$, therefore, appear to be induced after abdominal surgery. An increase of $T_{\text {regs }}$ has been described previously for trauma patients, ${ }^{22}$ and was associated with Th2 anti-inflammatory activity. $T_{\text {reg }}$ activation may be part of the explanation for decreased IFN- $\gamma$ release capacities in our patients.

The $\mathrm{CD}^{+} / \mathrm{CD} 8^{+}$ratio was reduced postoperatively in the present study. This result was not statistically significant, but in line with previous results from our group,${ }^{15}$ and typical of trauma patients. ${ }^{23}$

In contrast to $\mathrm{CD}^{+}{ }^{+} \mathrm{T}$-cells, $\mathrm{CD} 14^{+}$cell counts and various subpopulations were persistently increased after surgery, with the highest values observed at $24 \mathrm{~h}$. At $2 \mathrm{~h}$, the surface molecules CD16 and co-stimulatory CD86 were induced significantly when compared with the overall $\mathrm{CD} 14^{+}$population. $\mathrm{CD} 16$ is an $\mathrm{Fc}$ receptor that induces CD25 transcription and thus plays an important role in the interaction of $\mathrm{T}$-cells and APC. ${ }^{24}$ CD86 is a ligand for CD28 on T-cells and provides co-stimulatory signals necessary for their activation and survival.

MHC II expression was likewise induced, an observation contrary to a previous study. ${ }^{6}$ This absence of MHC II suppression may be owing to the relatively mild hemorrhage in our patients who did not experience massive hemorrhagic shock. Alternatively, MHC II expression may have been caused by direct stimulation with LPS in the ensuing experiments.

The strongest induction of any cell type was observed for $\mathrm{CD}_{14}{ }^{+} \mathrm{HLA}-\mathrm{DR}^{-}$cells. This subset belongs to the so-called MDSC ${ }^{25}$ which have been shown to be up-regulated after trauma. ${ }^{13,26}$ Increased production of arginase- 1 by MDSC results in depleted arginine levels. ${ }^{2}$ As arginine is required for lymphocyte proliferation and the formation of the T-cell receptor, ${ }^{27}$ the induction of MDSC provides a mechanism for impaired T-cell immunoproliferative responses and cytokine production in postoperative patients. Arginase-1 may also be produced by alternatively-activated macrophages under the influence of Th2 cytokines or regulatory macrophages. ${ }^{28}$ As macrophage differentiation and activation typically takes more than $48 \mathrm{~h}$, it probably did not occur in the present study, but cannot be excluded without positive identification of the cell types involved.

In co-culture experiments, secretion of IL-6 and TNF from macrophages after surgical trauma was increased independently from co-incubation with pre- or postoperative T-cells. This implies a T-cell-independent mechanism for macrophage activation and cytokine secretion by these cells.

As for IFN- $\gamma$, secretion was suppressed $2 \mathrm{~h}$ after surgery when either postoperative T-cells or APC were coincubated with the lowest values observed when both cell-types had been collected postoperatively. At the same time, GM-CSF secretion was significantly increased. This indicates that T-cell suppression may specifically concern IFN- $\gamma$, but not GM-CSF secretion, as observed in previous animal studies. ${ }^{4}$

The interpretation of co-culture results is limited by unspecific effects that the freezing process might have had on APC. IL-12 and TNF secretion was significantly suppressed in all systems that contained frozen APC irrespective of the T-cells used. We were, therefore, not able to reproduce IL-12 measurements from our previous animal study. ${ }^{3}$ Damage to APC during the freezing or thawing process must therefore be assumed, and conclusions about the effect of postoperative T-cells on IL12 release from APC cannot be drawn from these data. The duration of freezing, nonetheless, had no influence on cytokine secretion. The fact that T-cells were suppressed in spite of insufficient IL-12 release implies an IL-12-independent mechanism for T-cell suppression. Apparently, freezing did not alter T-cell function, as observed by preserved IFN- $\gamma$ and GM-CSF secretion.

Aiming for maximum stimulation of both APC and T-cells, all co-cultures in the present study were stimulated with both LPS and anti-CD3/anti-CD28. As LPS is able to stimulate T-cells via TLR4, ${ }^{29} \mathrm{~T}$-cell function in co-cultures may have been stimulated by LPS independent of their interaction with APC. Future studies should account for this by stimulation with either LPS or anti-CD3/anti-CD28, depending on the target cell that is being examined.

In conclusion, in the present study, T-cells were suppressed early after major abdominal surgery, while APC were persistently activated independently of T-cell function. T-cell suppression was associated with increased $\mathrm{T}_{\text {reg }}$ activity and a marked induction of CD $14^{+}$HLA-DR $^{-}$MDSC. While cytokine secretion by APC in co-cultures was significantly increased postoperatively, only a transient decrease at $2 \mathrm{~h}$ not reflecting the numeric decrease could be demonstrated for T-cell-derived IFN- $\gamma$. Further studies are needed to define the role of specific surface markers and cytokines in postoperative immunosuppression.

\section{Funding}

This research received no specific grant from any funding agency in the public, commercial or not-for-profit sectors.

\section{References}

1. Angele MK and Chaudry IH. Surgical trauma and immunosuppression: Pathophysiology and potential immunomodulatory approaches. Langenbecks Arch Surg 2005; 390: 333-341. 
2. Marik PE and Flemmer M. The immune response to surgery and trauma: Implications for treatment. J Trauma Acute Care Surg 2012; 73: 801-808.

3. Walz CR, Zedler S, Schneider CP, et al. Depressed t cell-derived ifn-gamma following trauma-hemorrhage: A potential mechanism for diminished apc responses. Langenbecks Arch Surg 2007; 392: 339-343.

4. Walz CR, Zedler S, Schneider CP, et al. The potential role of t-cells and their interaction with Ag-presenting cells in mediating immunosuppression following trauma-hemorrhage. Innate Immun 2009; 15: 233-241.

5. Angele MK and Faist E. Clinical review: Immunodepression in the surgical patient and increased susceptibility to infection. Crit Care 2002; 6: 298-305.

6. Ayala A, Ertel W and Chaudry IH. Trauma-induced suppression of Ag presentation and expression of major histocompatibility class II Ag complex in leukocytes. Shock 1996; 5: 79-90.

7. Angele MK, Knoferl MW, Schwacha MG, et al. Sex steroids regulate pro- and anti-inflammatory cytokine release by macrophages after trauma-hemorrhage. Am J Physiol 1999; 277: C35-C42.

8. Ertel W, Keel M, Neidhardt R, et al. Inhibition of the defense system stimulating interleukin-12 interferon-gamma pathway during critical illness. Blood 1997; 89: 1612-1620.

9. Samelson LE, Harford JB and Klausner RD. Identification of the components of the murine $\mathrm{t}$ cell $\mathrm{Ag}$ receptor complex. Cell 1985; 43: 223-231.

10. Yanagi Y, Yoshikai Y, Leggett K, et al. A human t cell-specific cdna clone encodes a protein having extensive homology to immunoglobulin chains. Nature 1984; 308: 145-149.

11. Jenkins MK, Taylor PS, Norton SD and Urdahl KB. Cd28 delivers a costimulatory signal involved in Ag-specific il-2 production by human t cells. J Immunol 1991; 147: 2461-2466.

12. Ochoa JB, Bernard AC, O'Brien WE, et al. Arginase i expression and activity in human mononuclear cells after injury. Ann Surg 2001; 233: 393-399.

13. Zhu X, Herrera G and Ochoa JB. Immunosupression and infection after major surgery: A nutritional deficiency. Crit Care Clin 2010; 26: 491-500.

14. Delon J, Stoll S and Germain RN. Imaging of t-cell interactions with $\mathrm{Ag}$ presenting cells in culture and in intact lymphoid tissue. Immunol Rev 2002; 189: 51-63.

15. Walz C, Zedler S, Schneider C, et al. The potential role of t-cells and their interaction with $\mathrm{Ag}$ presenting cells in mediating immunosuppression following trauma-hemorrhage. Innate Immun 2009; 15: 233-241.

16. Angele MK, Ayala A, Cioffi WG, et al. Testosterone: The culprit for producing splenocyte immune depression after trauma hemorrhage. Am J Physiol 1998; 274: C1530-C1536.

17. Kawasaki T, Fujimi S, Lederer JA, et al. Trauma-hemorrhage induces depressed splenic dendritic cell functions in mice. J Immunol 2006; 177: 4514-4520.

18. Vendetti S, Chai JG, Dyson J, et al. Anergic t cells inhibit the Agpresenting function of dendritic cells. J Immunol 2000; 165: $1175-1181$.

19. Chen W, Jin W, Hardegen N, et al. Conversion of peripheral CD4+CD25- naive $\mathrm{T}$ cells to $\mathrm{CD} 4+\mathrm{CD} 25+$ regulatory $\mathrm{T}$ cells by TGF-beta induction of transcription factor FOXP3. $J$ Exp Med 2003; 198: 1875-1886.

20. Caruso A, Licenziati S, Corulli M, et al. Flow cytometric analysis of activation markers on stimulated t cells and their correlation with cell proliferation. Cytometry 1997; 27: 71-76.

21. Wing K, Suri-Payer E and Rudin A. CD4+CD25+-regulatory T cells from mouse to man. Scand J Immunol 2005; 62: 1-15.

22. MacConmara MP, Maung AA, Fujimi S, et al. Increased CD4+ $\mathrm{CD} 25+\mathrm{T}$ regulatory cell activity in trauma patients depresses protective TH1 immunity. Ann Surg 2006; 244: 514-523.

23. Faist $\mathrm{E}$ and Wichmann MW. Immunology in the severely injured. Chirurg 1997; 68: 1066-1070. [article in German].

24. Anegón I, Cuturi MC, Trinchieri G and Perussia B. Interaction of Fc receptor (CD16) ligands induces transcription of interleukin 2 receptor $(\mathrm{CD} 25)$ and lymphokine genes and expression of their products in human natural killer cells. J Exp Med 1988; 167: 452-472.

25. Greten TF, Manns MP and Korangy F. Myeloid derived suppressor cells in human diseases. Int Immunopharmacol 2011; 11: 802-807.

26. Bryk JA, Popovic PJ, Zenati MS, et al. Nature of myeloid cells expressing arginase 1 in peripheral blood after trauma. $J$ Trauma 2010; 68: 843-852.

27. Rodriguez PC, Zea AH, Culotta KS, et al. Regulation of T cell receptor CD3zeta chain expression by L-arginine. J Biol Chem 2002; 277: 21123-21129.

28. Mosser DM and Edwards JP. Exploring the full spectrum of macrophage activation. Nat Rev Immunol 2008; 8: 958-969.

29. Pasare C and Medzhitov R. Toll pathway-dependent blockade of CD4+CD25+ T cell-mediated suppression by dendritic cells. Science 2003; 299: 1033-1036. 